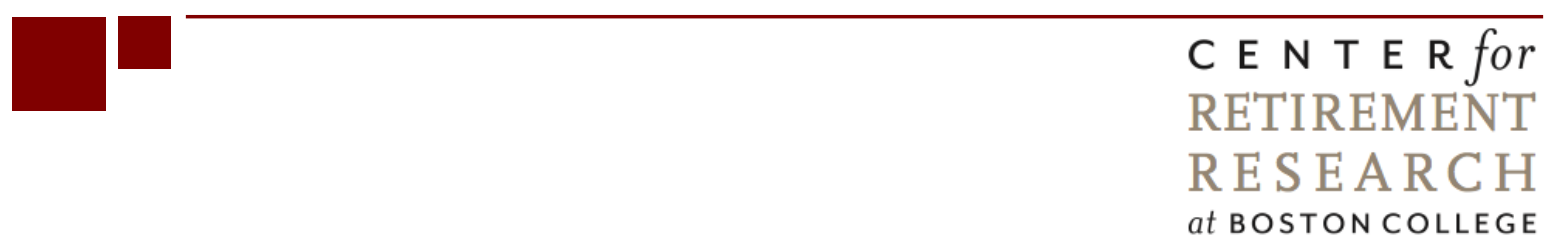

\title{
THE PENSION PROTECTION ACT OF 2006 AND DIVERSIFICATION OF EMPLOYER STOCK IN DEFINED CONTRIBUTION PLANS
}

\author{
Gary V. Engelhardt \\ CRR WP 2011-20 \\ Date Released: November 2011 \\ Date Submitted: October 2011
Center for Retirement Research at Boston College
Hovey House
140 Commonwealth Avenue
Chestnut Hill, MA 02467
Tel: 617-552-1762 Fax: 617-552-0191
http://crr.bc.edu

Gary V. Engelhardt is a professor of economics at Syracuse University. The research reported here was performed pursuant to a grant from the U.S. Social Security Administration (SSA) funded as part of the Retirement Research Consortium (RRC). The opinions and conclusion expressed are solely those of the author and do not represent the opinions or policy of SSA, any agency of the federal government, the RRC, Syracuse University, or Boston College.

(C) 2011, Gary V. Engelhardt. All rights reserved. Short sections of text, not to exceed two paragraphs, may be quoted without explicit permission provided that full credit, including (C) notice, is given to the source. 


\title{
About the Center for Retirement Research
}

The Center for Retirement Research at Boston College, part of a consortium that includes parallel centers at the University of Michigan and the National Bureau of Economic Research, was established in 1998 through a grant from the Social Security Administration. The Center's mission is to produce first-class research and forge a strong link between the academic community and decision-makers in the public and private sectors around an issue of critical importance to the nation's future. To achieve this mission, the Center sponsors a wide variety of research projects, transmits new findings to a broad audience, trains new scholars, and broadens access to valuable data sources.

\author{
Center for Retirement Research at Boston College \\ Hovey House \\ 140 Commonwealth Avenue \\ Chestnut Hill, MA 02467 \\ phone: 617-552-1762 fax: 617-552-0191 \\ e-mail: crr@bc.edu \\ crr.bc.edu
}

\section{Affiliated Institutions:}

The Brookings Institution Massachusetts Institute of Technology

Syracuse University

Urban Institute 


\begin{abstract}
This paper estimates the short-run impact of the Pension Protection Act of 2006 (PPA2006) on holdings of employer stock in defined contribution pension plans. PPA2006 allowed participants in plans with employer stock to diversify their holdings. However, stand-alone ESOPs, i.e., those that do not allow employee elective deferrals or after-tax contributions, were exempt from this provision. Using detailed Form 5500 financial data for stand-alone ESOPs and those that allow employee elective deferrals or after-tax contributions, so-called KSOPs, from 2003-5 (before) and 2007-9 (after) the PPA and a quasi-experimental empirical framework, two primary empirical findings emerge. First, the share of plan assets in company stock fell 7 percentage points for KSOPs, because of the diversification provisions in PPA2006, a substantial decline. There was no change in holdings for stand-alone ESOPs. Second, most of the decline occurred in plans that had between 25-50 percent of plan assets in employer stock. Nonetheless, in 2009 still two-thirds of KSOPs had more than 10 percent of assets in company stock, the statutory limit for defined benefit pension plans.
\end{abstract}


Over the last two decades, policymakers and academics have expressed concern over the potential risk of substantial amounts of employer stock in defined contribution (DC) pension plans. In particular, for some workers, such holdings not only introduce a substantial amount of undiversifiable risk into the retirement-asset portfolio, but can be doubly costly due to a positive correlation between company stock prices, worker earnings, employment prospects in poorly performing firms. Layoffs and steep declines in share values at companies like Enron and Global Crossing, which resulted in catastrophic job losses as well as losses in 401(k) assets, brought many of these issues to the forefront in policy debates.

An important provision of the Pension Protection Act of 2006 (PPA2006) was the establishment of new rules on the diversification of DC assets away from employer stock as step toward addressing these concerns. This paper measures the extent to which DC plans have shifted the composition of plan assets away from employer stock as a result of the PPA diversification provisions. It adds to the findings of a number of previous studies that have attempted to elucidate and quantify the risks to diversification from holding company stock, including Brennan and Torous (1999), Benartzi (2001), Muelbrook (2002), Liang and Weisbenner (2002), Purcell (2002), Poterba (2003), Even and Macpherson (2004), Mitchell and Utkus (2004), Brown, Liang, and Weisbenner (2006, 2007), and Benartzi, Thaler, Utkus, and Sunstein (2007), among others. ${ }^{1}$

This study focuses on company stock held in DC plans that are Employee Stock Ownership Plans (ESOPs) for two reasons. First, many large firms that have significant shares of retirement-plan assets in company stock, including some of the more notorious cases, such as

\footnotetext{
${ }^{1}$ There has been relatively little written thus far on the economic impacts of PPA2006. Campbell, Dhaliwal, and Schwartz $(2009,2010)$ examined the impact of the DB funding provisions in the law on the cost of corporate debt and stock returns, respectively. Engelhardt (2011) examined the impact of the law on auto-enrollment in 401(k) plans.
} 
Enron, sponsor ESOPs that are combined with a traditional 401(k). These plans, also known as KSOPs, contain a substantial fraction of DC assets overall held in employer stock. Second, the PPA diversification provisions were targeted differentially within ESOP plans. Prior to 2006, ESOP plan participants who were 55 and older with 10 years of participation were eligible to diversify their company-stock holdings. Starting in 2007, the PPA required DC plans with company stock to allow participants with 3 or more years of service, regardless of age, to diversify their holdings in those securities. Importantly, within ESOPs, these new rules only apply to KSOPs. This distinction generates natural comparison groups with which to identify the short-run impact of the PPA on company-stock holdings. In particular, the behavior of KSOPs, which were subject to the diversification provisions, can be compared to that of stand-alone ESOPs, which were exempt, before versus after 2006, using a quasi-experimental methodology.

Using detailed Form 5500 financial data on all ESOPs from 2003-2009, i.e., before and after the PPA, two primary empirical findings emerge. First, the share of plan assets in company stock fell 7.1 percentage points for KSOPs. There was no change in holdings for stand-alone ESOPs. Since the pre-2006 average share of company stock in KSOPs was $37.4 \%$, the diversification effect for these plans has been substantial. Second, when weighted by participants, the shift away from company stock in KSOPs has been even larger, an 11 percentage-point decline, because the declines have occurred differentially in larger plans. In fact, most of the decline in company-stock holdings because of PPA2006 has occurred in plans that had between 25-50\% of plan assets in employer stock. Nonetheless, in 2009 still two-thirds of KSOPs had more than $10 \%$ of assets in company stock, the statutory limit for defined benefit (DB) pension plans, suggesting that, despite the PPA provisions, substantial retirement assets may still be subject to undiversifiable company-stock risk. 
This paper is organized as follows. Section I provides brief background on PPA2006. Section II discusses the Form 5500 data and methods used in the empirical analysis. The empirical results are presented in section III. There is a brief conclusion.

\section{Background on the Pension Protection Act of 2006}

The Pension Protection Act of 2006 (PPA2006) has been viewed by many as the most important piece of pension legislation since the passage of the Employee Retirement Income Security Act (ERISA) in 1974. Although many of the main provisions applied to DB plans, the law contained a number of important changes for DC plans. These are discussed in detail in Purcell (2006a).

Since 1987, Section 401(a)(28) of the Internal Revenue Code (IRC) governed diversification of employer stock in ESOPs. It held that plans with such stock had to allow qualified participants to diversify out of employer stock. A "qualified participant” was defined as being at least age 55 and with 10 years of participation in the ESOP. In addition, the timing of the diversification was allowed in the six-year period after qualification, within which, as much as $25 \%$ of company-stock holdings could be divested in each of the first five years, and as much as $50 \%$ in the sixth year. The actual diversification election could occur once per year within a 90-day window after the conclusion of each plan year. Essentially, diversification was phased and limited to longer-tenure workers at the end of their careers.

By adding IRC Section 401(a)(35), the PPA eased restrictions on diversification in a number of ways. First, it changed the definition of a qualified participant to any participant with at least three years of service, regardless of age. Second, upon qualification, the participant could divest $100 \%$ of the account for contributions after 2007. Contributions prior to 2007 are 
allowed to be divested over a 3-year period, one-third per year (Burgess, 2011). Third, the Act required that the diversification election be offered at least once per quarter. The diversification itself had to occur across at least 3 investment funds of materially different risk and return characteristics, effectively in accordance with IRC Section 404(c).

Importantly, the diversification provisions in the PPA applied to all DC plans with assets held in employer stock, with the exception of stand-alone ESOPs, i.e., those that do not allow for elective pre-tax deferrals under Section 401(k) or after-tax deferrals under Section 401(m) was exempt from these requirements. This exception is critical to the identification strategy for the empirical analysis outlined below. ${ }^{2}$

Two other DC provisions in the PPA are relevant for this study. The Act clarified that federal law allowing negative elections in 401(k)s superseded state wage-payment laws that in some states forbade employers from making deductions from pay without the written consent of the employee. These laws were seen as impediments to the adoption of automatic enrollment in 401(k) plans, and, after PPA2006, there was a substantial expansion in auto-enrolled 401(k)s (Purcell, 2006b; Nessmith, Utkus, and Young, 2007; VanDerhei, 2010; Engelhardt, 2011). The PPA also set out safe-harbor provisions for nondiscrimination testing in auto-enrolled 401(k)s. Therefore, at the same time that plans with employee elective deferrals were allowing many participants to diversify holdings in company stock, there was an economy-wide expansion in employee deferrals in auto-enrolled 401(k) plans.

\footnotetext{
${ }^{2}$ There is some ambiguity as to whether the diversification provisions also apply to stock bonus plans that do not allow employee elective deferrals or after-tax contributions. Technically, these are profit-sharing plans that make the discretionary employer contributions in the form of stock. Stock bonus plans are often treated synonymously with ESOPs (Allen, Melone, Rosenblum, and Mahoney, 2003). However, the transitional and final regulations concerning employer-stock diversification only specifically mentioned ESOPs. For this reason, the empirical analysis below focuses only on ESOPs. When the analysis sample is expanded to include stock bonus plans, the results are qualitatively and quantitatively similar.
} 


\section{Data and Empirical Methods}

\section{A. Data and Aggregate Statistics}

The data for the empirical analysis below are drawn from annual IRS Form 5500 filings from 2003-2009 for all DC plans with 100 or more participants. ${ }^{3}$ For the purposes of the analysis, "plans” are defined by a unique employer identification number (EIN) assigned to the plan sponsor and plan number (PN). For each plan and year, Schedule H from the 5500 contains the plan's financial data, including the amount of assets in employer securities and in total for the plan. All asset amounts are measured as of the end of the filing year. All multiemployer and collectively bargained plans are excluded from the analysis, as are nonqualified, non-U.S., and non-for-profit employer plans, such as 403(b)s. Plans with missing information on EIN, PN, and plan assets were excluded as well. Overall, for 2003-9 the sample for the aggregate statistics in Tables 1 and 2 contains 72,601 unique DC plans and 352,338 plan-year observations.

Previous studies have documented that there are a relatively small number of DC plans with company stock. However, these are relatively large plans in terms of the number of participants. Thus, the total number of individuals potentially affected by retirement income exposure to company stock is large (Liang and Weisbenner, 2002; Mitchell and Utkus, 2004; Purcell, 2002; among others).

The results in Table 1, which gives basic aggregate statistics for all DC plans by year, bear this out. In 2003, out of a total of 47,972 DC plans (column 1), 4,104, or 8.6\%, had company stock as an asset (columns 2 and 3, respectively). However, these plans averaged 3,551 participants (column 5), about four times the average for all plans (column 4). Therefore, of the 44 million DC plan participants then (column 6), 14.6 million were in plans potentially

\footnotetext{
${ }^{3}$ The filings for 2010 were only about one-third complete at the time of writing, so these data were not included in the analysis.
} 
exposed to company stock risk (column 7). This corresponded to one-third of all DC plan participants (column 8).

Looking across years, a few basic time-series patterns emerge. First, the share of plans with company stock has fallen. Prior to 2006, roughly 8.3\% of DC plans had company stock (column 3). By 2009, this share had fallen to 6.8\%. Second, the average size of plans with company stock, as measured by number of participants, has risen by about $10 \%$ (column 5), suggesting shifts in the composition of firms with company stock. Finally, the fraction of participants in plans with company stock has fallen from around 32\% prior to 2006 to roughly 28\% after 2006 (column 8).

Table 2 shows the fraction of total plan assets held in company stock for 2003-9. In 2003, company stock comprised just over 4\% of total assets for all DC plans (column 1). However, for the subsample of plans that have company stock (column 2), such stock occupied just over $50 \%$ of all plan assets. Column 3 shows the real total market value of company stock in 2009 dollars, using the all-items Consumer Price Index as the deflator. The aggregate amount of company stock in DC plans has fallen rather dramatically since 2003 (from \$217B to \$166B), because of a decline in the number of plans with company stock (column 2, Table 1) and the market-wide decline in share prices during the financial crisis and Great Recession. Expressed on a per participant basis, the value of company stock has fallen from around \$15,000 in 2003 to just under \$12,000 in 2009.

\section{B. Empirical Methods}

The basic empirical approach is a difference-in-difference analysis, comparing the share of company stock in KSOPs to stand-alone ESOPs, before versus after 2006. Company stock in 
ESOPs represented $76 \%$ of all company stock in DC plans and $67 \%$ of all participants with company stock in DC plans prior to 2006. This strategy will identify the short-run impact of PPA2006 as long as there are no other reasons why company stock as a share of plan assets would be changing, relatively, for plans with and without elective deferrals at this time. The alternative that there may have been some other shock over this time period that caused a relative shift in company-stock holdings cannot be ruled out completely, but it seems somewhat unlikely given the prominence and industry coverage of the diversification provisions in PPA2006. However, special attention in the empirical analysis will be paid to the expansion of autoenrollment in 401(k) plans during this time period, much of which was spurred by the PPA2006, an obvious potential confounder.

\section{Empirical Results}

\section{A. Simple Difference-in-Difference Evidence}

Table 3 shows data on the share of assets held in company stock for all ESOPS by the presence of elective deferrals and time periods. Throughout the remainder of the paper, the term “elective deferrals” will refer to both pre-tax deferrals under Section 401(k) and after-tax deferrals under Section 401(m). The sample is comprised of 14,463 ESOP plan-year observations. In the first row of panel A, there is a decrease in the company-stock share for ESOPs that allow elective deferrals (KSOPs) of 6.7 percentage points. These plans were subject to the diversification provisions in the PPA. In the second row, there essentially was no change in the company-stock share for stand-alone ESOPs. These plans were not subject to the diversification provisions. The difference-in-difference estimate in the third row indicates that PPA2006 was associated with a 7.1 percentage-point decline in the share of assets in company 
stock. Given the pre-2006 average share of 37.4 percentage points (row 1, column 1), this is a substantive decline in company-stock holdings, on the order of $19 \%$ (i.e., $0.19=0.071 / 0.374$ ). As most company stock is held in relatively larger plans (Table 1), panel B in Table 3 undertakes a corresponding difference-in-difference calculation weighting plans by the number of participants. The bottom row indicates that PPA2006 was associated with a somewhat larger decline in the share of assets in company stock of 13.2 percentage points. Overall, these results suggest that the diversification provisions in the PPA had some impact on the holdings of company stock. To explore this further, the analysis next moves to a regression framework.

\section{B. Regression-Based Evidence}

Let $i, j$, and $t$, index the plan, industry, and calendar year, respectively. Then Table 4 presents estimates from the following econometric specification:

$$
S_{i j t}=\alpha+\beta D_{i j t}^{\text {Elective }}+\delta D_{i j t}^{\text {Elective }} \times D_{t}^{\text {After2006 }}+\gamma_{t}+\mu_{j}+u_{i j t} \text {, }
$$

where the dependent variable, $S$, is the share of plan assets in company stock; $D^{\text {Elective }}$ is a dummy variable that takes on a value of one if the plan allowed elective deferrals (KSOP); $D^{\text {After } 2006}$, is a dummy that takes on a value of one if the calendar year was after 2006; $\gamma$ is a vector of calendar-year dummies; $\mu$ is a vector of industry dummies; and $u$ is a disturbance term. The primary objective is to obtain consistent estimates of $\delta$, which represent the difference-indifference estimates of the impact of the PPA company-stock diversification provisions on company-stock holdings in ESOPs. The key identifying assumption is that there were no other changes in the pension landscape during the 2003-9 period that differentially affected the company-stock holdings of stock-based plans that allow elective deferrals, but not those that do not allow such deferrals. 
Industry is measured using the six-digit business code on the Form 5500. This code is based on the North American Industry Classification System (NAICS). The first two digits of the code correspond to 18 broad industry classifications. The industry effects, $\mu$, used in (1) are at the three-digit level and correspond to 80 industrial classifications.

Column 1 of panel A of the table shows ordinary least squares (OLS) estimates of $\delta$, with standard errors clustered by plan sponsor (EIN) in parentheses. Relative to plans that do not allow elective deferrals, the share of company stock in plans with deferrals fell by 7 percentage points, controlling for calendar year and industry. This effect is highly statistically significant. ${ }^{4}$ Based on a pre-2006 average company-stock share in KSOPs of 37.4\% (the second row), this decline represents a sizable reduction in the share of company stocks associated with the PPA.

Panel B shows the least squares estimate of $\delta$, weighted by the number of plan participants. Relative to plans that do not allow deferrals, the share of company stock in plans with deferrals fell by 10.9 percentage points (column 1), controlling for calendar year and industry. Based on a pre-2006 weighted mean company-stock share in plans with deferrals of $27.5 \%$ (bottom row), this is a sizeable reduction as well.

A key issue is where in the distribution of the share of company-stock holdings the PPA provisions had the greatest impact. For example, the reductions in holdings could have been concentrated in plans that already had relatively high holdings, thus reducing the variance in company-stock exposure; alternatively, the reductions could have occurred disproportionately in plans that already had low holdings, potentially increasing the variance in company-stock exposure. To examine this, column 2 shows estimates of $\delta$ from

$$
D_{i j t}^{S>0.10}=\alpha+\beta D_{i j t}^{\text {Elective }}+\delta D_{i j t}^{\text {Elective }} \times D_{t}^{\text {After2006 }}+\gamma_{t}+\mu_{j}+u_{i j t},
$$

\footnotetext{
${ }^{4}$ Tobit estimates that explicitly recognize that the shares are bounded from below by zero and above by one wre very similar in magnitude and statistical significance.
} 
where the dependent variable is a dummy variable that takes on a value of one if the plan had more than $10 \%$ of assets in company stock and zero otherwise. Ten percent is the statutory limit on employer stock in DB plans. Columns 3-5 show the estimates from the same specification, but when the dependent variable has the company-stock threshold at shares of $25 \%, 50 \%$ and 75\%, respectively, i.e., as plans become increasingly concentrated in company stock.

The difference-in-difference estimates in columns 2-5 show that the largest absolute reductions in the share of company stock occurred for plans that had one-quarter or more of assets in company stock (column 3). However, the reductions relative to the pre-2006 average shares were largest for plans that had one-half or more of assets in company stock (columns 4 and 5). For example, after the PPA, the participant-weighted company-stock share fell by 17.6 percentage points in plans with one-half or more of assets in company stock (column 4), controlling for calendar year and industry, on a pre-2006 base of 23.8 percentage points (bottom row of the table), or a $74 \%$ reduction in the incidence of very highly concentrated plans.

\section{Extensions and Robustness Checks}

One potential concern with the estimates in Tables 3 and 4 is that the PPA contained other provisions for DC plans. If these other changes happened to have differentially affected company-stock holdings in plans with and without elective deferrals, then the key identification assumption in the difference-in-difference framework would be violated, rendering the estimates in Tables 3 and 4 biased and inconsistent. The most important of these provisions was the clarification of the legal status of auto-enrollment in $401(\mathrm{k}) \mathrm{s}$, and the establishment of rules for plan design that created a safe harbor for auto-enrolled 401(k)s from nondiscrimination testing. These two changes led to a rapid increase in the adoption of auto-enrolled 401(k) plans after 
2006 (Engelhardt, 2011), primarily in place of existing affirmative election 401(k)s. Under the PPA safe harbor rules, a plan with automatic enrollment will be deemed to have satisfied nondiscrimination testing if it provides a minimum employer matching contribution of $100 \%$ on elective deferrals up to $1 \%$ of employee pay, and $50 \%$ on elective deferrals between $1 \%$ and $6 \%$ of pay. If these matching contributions were not in company stock, this could have driven down the share of company stock in plans with elective deferrals after 2006, biasing the estimates in Tables 3-5 away from zero (i.e., making the effects of PPA seem bigger than in actuality).

To address this potential concern, Table 5 repeats the analysis in Table 4, but excludes from the sample the observations for all calendar years from plans that reported auto-enrollment in 2009. This strips from the sample any plan that ever adopted auto-enrollment. The difference-in-difference estimates in Table 5 are similar to those in Tables 3 and 4 . They show economically large and statistically significant declines in the share of company stock after relative to before 2006. It does not appear that the changes in auto-enrollment provisions were driving the earlier findings.

As a final extension, Table 6 provides some additional evidence based on three qualitative measures of diversification of employer stock after 2006. Column 1 shows estimates of $\delta$ from

$$
D_{i j t}^{404(c)}=\alpha+\beta D_{i j t}^{\text {Elective }}+\delta D_{i j t}^{\text {Elective }} \times D_{t}^{\text {After2006 }}+\gamma_{t}+\mu_{j}+u_{i j t},
$$

where the dependent variable is a dummy variable that takes on a value of one if the plan satisfies the requirements for a Section 404(c) safe harbor for plan investment design. This safe harbor is from fiduciary liability and allows a sponsor to offer company stock as an investment option, as long as the plan also offers at least three alternative investment options that have materially different risk and return properties. Under PPA2006, stock-based plans that allow 
elective deferrals are required to offer at least three alternative investment options and let participants diversify balances in company stock. Essentially, the PPA requires such plans to satisfy the Section 404(c) safe harbor. Again, stock-based plans without elective deferrals are exempt from this under the PPA. Therefore, if PPA2006 had a material effect on plan diversification, then $\delta$ in (3) should be positive. The difference-in-difference estimate of $\delta$ in panel A of column 1 of the table is positive, economically large, and highly statistically significant. It suggests that the fraction of plans with elective deferrals that satisfy the requirements of Section 404(c) rose by almost 9 percentage points relative to plans without, after relative to before the enactment of the PPA. The participant-weighted estimate in panel B is also positive, but less precisely estimated.

Column 2 shows estimates of $\delta$ from

$$
D_{i j t}^{\text {PartialDirect }}=\alpha+\beta D_{i j t}^{\text {Elective }}+\delta D_{i j t}^{\text {Elective }} \times D_{t}^{\text {After2006 }}+\gamma_{t}+\mu_{j}+u_{i j t} \text {, }
$$

where the dependent variable is a dummy variable that takes on a value of one if the plan design allows the participant to only partially direct the investment of assets in the plan. As many stock-based plans placed restrictions on the ability of participants to direct the investment of assets, especially employer contributions in the form of employer stock, the incidence of partial direction should have fallen with the adoption of the diversification provisions under the PPA. Hence, $\delta$ in (4) should be negative. The difference-in-difference estimate of $\delta$ in panel A of column 2 of the table is negative, modest in size, but highly statistically significant. It suggests that the fraction of plans with elective deferrals that had only partial participant direction fell by 8.3 percentage points relative to plans without, after relative to before the enactment of the PPA. The participant-weighted estimate in panel B is also negative, but suggests impacts of the PPA that are much larger in magnitude. 
Finally, column 3 shows estimates of $\delta$ from

$$
D_{i j t}^{\text {RequiresCS }}=\alpha+\beta D_{i j t}^{\text {Elective }}+\delta D_{i j t}^{\text {Elective }} \times D_{t}^{\text {After2006 }}+\gamma_{t}+\mu_{j}+u_{i j t},
$$

where the dependent variable is a dummy variable that takes on a value of one if the plan design requires employer contributions to the plan to be held in the form of company stock (CS). The incidence of this plan feature should have fallen with the adoption of the diversification provisions under the PPA. Hence, $\delta$ in (5) should be negative. The difference-in-difference estimate of $\delta$ in panel A of column 3 of the table is negative, economically large, and highly statistically significant. It suggests that the fraction of plans with elective deferrals that required employer contributions in stock fell by 4 percentage points relative to plans without, after relative to before the enactment of the PPA. The participant-weighted estimate in panel B is also negative and large. Overall, the evidence in Table 6 on the incidence of plan features is consistent with the quantitative evidence on company-stock shares in Tables 3-5. Together, the empirical results in these tables suggest that in the short run the PPA induced a substantive amount of diversification of employer stock in DC plan.

\section{Conclusion}

This study has focused on the short-run impact of the diversification rules in PPA2006 on holdings of company stock in DC plans, in general, and ESOPs, in particular. Using detailed Form 5500 financial data on all ESOP plans from 2003-2009, i.e., before and after the PPA, two primary empirical findings emerge. First, the share of plan assets in company stock fell 7.1 percentage points for KSOPs, because of the diversification provisions in PPA2006. There was no change in holdings for stand-alone ESOPs, which were exempt from the new rules. Since the 
pre-2006 average share of company stock in KSOPs was 37.4\%, the diversification effect for KSOPs has been substantial. Second, when weighted by participants, the shift away from company stock in KSOPs has been even larger, an 11 percentage-point decline. This reflects that the declines have occurred differentially in larger plans. In fact, most of the decline in company-stock holdings because of PPA2006 has occurred in plans that had between 25-50\% of plan assets in employer stock. Overall, there has been a substantive amount of diversification of employer stock in DC plan. Nonetheless, in 2009 still two-thirds of KSOPs had more than 10\% of assets in company stock, the statutory limit for defined benefit pension plans, suggesting that, despite the PPA provisions, substantial retirement assets may still be subject to undiversifiable company-stock risk.

There are two important caveats to this analysis. First, this is only a short-run impact analysis. In particular, for some plans in the "after" period, the phase-in of the diversification of company stock accumulated prior to 2006 had not fully occurred (these were to be phased in over a three-year period). Therefore, almost surely the estimates in the paper are lower bounds on the movement out of company stock in ESOPs. Second, a key policy issue is the determination of the composition and risk profile of the new assets in the affected plans from what was formerly employer stock: in particular, when participants diversified out of positions in company stock, where did that money go? Into money-market funds, bond funds, stock funds, etc.? This is a key next step in determining just how much PPA2006 has reduced undiversifiable retirement-income risk, and important avenue for future research. 


\section{References}

Allen, Everett T., Joseph J. Malone, Jerry S. Rosenbaum, and Dennis F. Mahoney, 2003.

Pension Planning: Pension, Profit-Sharing, and Other Deferred Compensation Plan, $9^{\text {th }}$ Edition (Boston: McGraw-Hill Irwin).

Benartzi, Shlomo. 2001. "Excessive Extrapolation and the Allocation of 401(k) Accounts to Company Stock,” Journal of Finance 56: 1747-1764.

Benartzi, Shlomo, and Richard H. Thaler. 2001. "Naïve Diversification Strategies in Defined Contribution Saving Plans,” American Economic Review 91: 79-98.

Benartzi, Shlomo, Richard H. Thaler, Stephen Utkus, and Cass R. Sunstein. 2007. "The Law and Economics of Company Stock in 401(k) Plans,” Journal of Law and Economics 50: 7998.

Brennan, Michael J., and Walter N. Torous. 1999. "Individual Decision Making and Investor Welfare,” Economic Notes 28: 119-143.

Brown, Jeffrey R., Nellie Liang, and Scott Weisbenner. 2006. “401(k) Matching Contributions in Company Stock: Costs and Benefits for Firms and Workers,” Journal of Public Economics 90:6-7: 1315-1346.

Brown, Jeffrey R., Nellie Liang, and Scott Weisbenner. 2007. "Individual Account Investment Options and Portfolio Choice: Behavioral Lessons from 401(k) Plans,” Journal of Public Economics 91:10: 1992-2013.

Burgess, M. John, 2011. "Strategies for ESOPs Under the New Diversification Requirements,” Compensation Benefits Review 43: 39-45.

Campbell, John L., Dan S. Dhaliwal, and William C. Schwartz, 2009. "Do Mandatory Pension Contributions Lead to Increases in Firms’ Cost of Debt,” Mimeo., University of Arizona.

Campbell, John L., Dan S. Dhaliwal, and William C. Schwartz, 2010. "Equity Valuation Effects of the Pension Protection Act of 2006,” Contemporary Accounting Research 27:2, 469536.

Engelhardt, Gary V. 2011. "State Wage-Payment Laws, the Pension Protection Act of 2006, and 401(k) Saving Behavior,” Economics Letters 113: 237-40.

Even, William E., and David Macpherson. 2004. “Company Stock in Pension Funds,” National Tax Journal 57: 299-313.

Liang, Nellie, and Scott Weisbenner, 2002. "Investor Behavior and the Purchase of Company Stock in 401(k) Plans—The Importance of Plan Design,” NBER Working Paper 9131. 
Mitchell, Olivia S., and Stephen P. Utkus. 2004. "The Role of Company Stock in Defined Contribution Plans,” in Olivia S. Mitchell and Kent Smetters (eds.) The Pension Challenge: Risk Transfers and Retirement Income (Oxford: Oxford University Press), pp. 33-70.

Muelbroek, Lisa. 2002. "Company Stock in Pension Plans: How Costly is it?” Harvard Business School Working Paper 02-058.

Nessmith, William E., Stephen P. Utkus, and Jean Young. 2007. "Measuring the Effectiveness of Automatic Enrollment,” Vanguard Center for Retirement Research, Volume 31, Philadelphia, PA.

Poterba, James M. 2003. “Employer Stock and 401(k) Plans,” American Economic Review, 93:2: 398-404.

Purcell, Patrick. 2002. Employer Stock in Retirement Plans: Investment Risk and Retirement Security (Washington DC: Congressional Research Service).

Purcell, Patrick. 2006a. Summary of the Pension Protection Act of 2006 (Washington DC: Congressional Research Service).

Purcell, Patrick. 2006b. Automatic Enrollment in 401(k) Plans (Washington, D.C.: Congressional Research Service).

VanDerhei, Jack, “The Impact of Automatic Enrollment in 401(k) Plans on Future Retirement Accumulations,” Employee Benefit Research Institute, Washington, D.C., 2010. 
Table 1. Annual Statistics on Number of Plans and Participants in DC Plans Overall and those with Company Stock, 2003-2009.

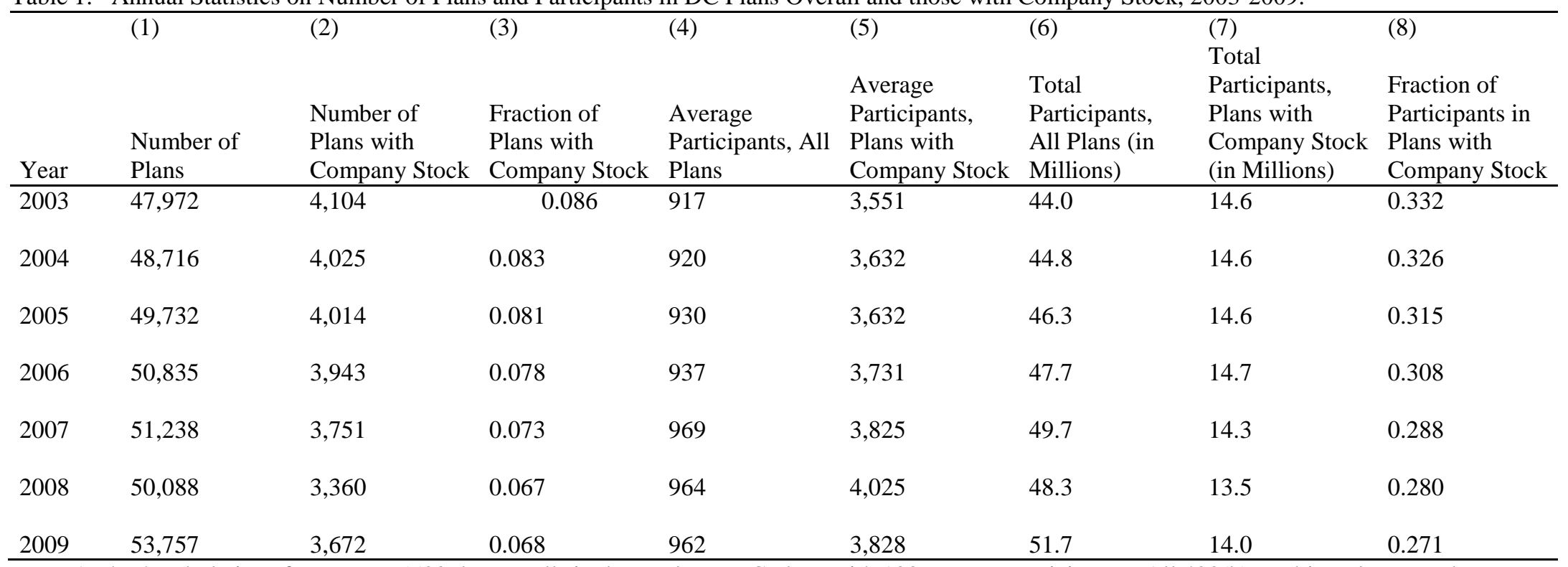

Note: Author's tabulations from Form 5500 data on all single-employer DC plans with 100 or more participants. All 403(b), multiemployer, and collectively bargained plans have been excluded from the sample. Column 3 is column 2 divided by column 1 ; column 8 is column 7 divided by column 6. 
Table 2. Fraction of Total Plan Assets in Company Stock by Year, for All DC Plans and Plans with Company Stock, Respectively

\begin{tabular}{|c|c|c|c|c|}
\hline & (1) & (2) & (3) & $(4)$ \\
\hline Year & $\begin{array}{l}\text { Fraction of Plan Assets } \\
\text { Invested in Company } \\
\text { Stock, All Plans }\end{array}$ & $\begin{array}{l}\text { Fraction of Plan Assets } \\
\text { Invested in Company } \\
\text { Stock, Plans with } \\
\text { Company Stock }\end{array}$ & $\begin{array}{l}\text { Amount of } \\
\text { Company Stock (in } \\
\text { Billions of \$2009) }\end{array}$ & $\begin{array}{l}\text { Amount of Company } \\
\text { Stock per Participant } \\
\text { in Plans with } \\
\text { Company Stock (in } \\
\text { Thousands of } \$ 2009 \text { ) }\end{array}$ \\
\hline 2003 & 0.043 & 0.503 & 217.2 & 14.9 \\
\hline 2004 & 0.042 & 0.505 & 231.0 & 15.8 \\
\hline 2005 & 0.041 & 0.505 & 225.2 & 15.5 \\
\hline 2006 & 0.040 & 0.510 & 230.8 & 15.7 \\
\hline 2007 & 0.038 & 0.514 & 204.7 & 14.3 \\
\hline 2008 & 0.033 & 0.498 & 135.5 & 10.0 \\
\hline 2009 & 0.036 & 0.520 & 166.1 & 11.8 \\
\hline
\end{tabular}

Note: Author's tabulations from Form 5500 data on all single-employer DC plans with 100 or more participants. 
Table 3. Difference-in-Difference Estimates of PPA2006 on Share of Assets Held in Company Stock for All ESOPs (Standard Errors Clustered by Plan Sponsor in Parentheses)

\begin{tabular}{|c|c|c|c|}
\hline Group /year & $\begin{array}{l}1) \\
\text { Before } \\
\text { PPA2006 } \\
\end{array}$ & $\begin{array}{l}(2) \\
\text { After } \\
\text { PPA2006 }\end{array}$ & $\begin{array}{l}\text { (3) } \\
\text { Time difference } \\
\text { for groups }\end{array}$ \\
\hline \multicolumn{4}{|l|}{ A. Unweighted } \\
\hline Plans with elective deferrals & $\begin{array}{l}0.374 \\
(0.0112)\end{array}$ & $\begin{array}{l}0.307 \\
(0.0111)\end{array}$ & $\begin{array}{l}-0.0674 \\
(0.0101)\end{array}$ \\
\hline Plans without elective deferrals & $\begin{array}{l}0.794 \\
(0.00657)\end{array}$ & $\begin{array}{l}0.798 \\
(0.00622)\end{array}$ & $\begin{array}{l}0.00389 \\
(0.00711)\end{array}$ \\
\hline Difference-in-difference & & & $\begin{array}{l}-0.0713 \\
(0.0124)\end{array}$ \\
\hline \multicolumn{4}{|l|}{ B. Weighted by Participants } \\
\hline Plans with elective deferrals & $\begin{array}{l}0.293 \\
(0.0403)\end{array}$ & $\begin{array}{l}0.181 \\
(0.0291)\end{array}$ & $\begin{array}{l}-0.112 \\
(0.0205)\end{array}$ \\
\hline Plans without elective deferrals & $\begin{array}{l}0.758 \\
(0.0333)\end{array}$ & $\begin{array}{l}0.778 \\
(0.0284)\end{array}$ & $\begin{array}{l}0.0198 \\
(0.0309)\end{array}$ \\
\hline Difference-in-difference & & & $\begin{array}{l}-0.132 \\
(0.0368)\end{array}$ \\
\hline
\end{tabular}


Table 4. Parameter Estimates of the Impact of Diversification Provisions from PPA2006 on Selected Measures of Company-Stock Holdings in ESOPs (Standard Errors Clustered by Plan Sponsor in Parentheses)

\begin{tabular}{|c|c|c|c|c|c|}
\hline Explanatory Variable & $\begin{array}{l}\text { Share of Assets in } \\
\text { Company Stock }\end{array}$ & $\begin{array}{l}\text { (2) } \\
\text { Dummy if Share } \\
\text { of Assets in } \\
\text { Company Stock } \\
\text { Greater than } 10 \%\end{array}$ & $\begin{array}{l}\text { (3) } \\
\text { Dummy if Share } \\
\text { of Assets in } \\
\text { Company Stock } \\
\text { Greater than } 25 \%\end{array}$ & $\begin{array}{l}\text { (4) } \\
\text { Dummy if Share } \\
\text { of Assets in } \\
\text { Company Stock } \\
\text { Greater than } 50 \%\end{array}$ & $\begin{array}{l}\text { (5) } \\
\text { Dummy if Share } \\
\text { of Assets in } \\
\text { Company Stock } \\
\text { Greater than } 75 \%\end{array}$ \\
\hline $\begin{array}{l}\text { A. Unweighted } \\
D^{\text {Elective }} \times D^{\text {After } 2006}\end{array}$ & $\begin{array}{l}-0.070 \\
(0.012)\end{array}$ & $\begin{array}{l}-0.089 \\
(0.018)\end{array}$ & $\begin{array}{l}-0.122 \\
(0.019)\end{array}$ & $\begin{array}{l}-0.099 \\
(0.017)\end{array}$ & $\begin{array}{l}-0.039 \\
(0.015)\end{array}$ \\
\hline Pre-2006 unweighted mean for plans with elective deferrals & 0.374 & 0.747 & 0.594 & 0.346 & 0.153 \\
\hline $\begin{array}{l}\text { B. Weighted by Participants } \\
D^{\text {Elective }} \times D^{\text {After } 2006}\end{array}$ & $\begin{array}{l}-0.109 \\
(0.031)\end{array}$ & $\begin{array}{l}-0.133 \\
(0.052)\end{array}$ & $\begin{array}{l}-0.190 \\
(0.063)\end{array}$ & $\begin{array}{l}-0.176 \\
(0.075)\end{array}$ & $\begin{array}{l}-0.053 \\
(0.034)\end{array}$ \\
\hline Pre-2006 weighted mean for plans with elective deferrals & 0.293 & 0.665 & 0.550 & 0.238 & 0.050 \\
\hline
\end{tabular}


Table 5. Parameter Estimates of the Impact of Diversification Provisions from PPA2006 on Selected Measures of Company-Stock Holdings in ESOPs, All ESOPs Except those with Auto-Enrollment for Elective Deferrals (Standard Errors Clustered by Plan Sponsor in Parentheses)

\begin{tabular}{|c|c|c|c|c|c|}
\hline Explanatory Variable & $\begin{array}{l}\text { Share of Assets in } \\
\text { Company Stock }\end{array}$ & $\begin{array}{l}(2) \\
\text { Dummy if Share } \\
\text { of Assets in } \\
\text { Company Stock } \\
\text { Greater than } 10 \%\end{array}$ & $\begin{array}{l}\text { (3) } \\
\text { Dummy if Share } \\
\text { of Assets in } \\
\text { Company Stock } \\
\text { Greater than } 25 \%\end{array}$ & $\begin{array}{l}\text { (4) } \\
\text { Dummy if Share } \\
\text { of Assets in } \\
\text { Company Stock } \\
\text { Greater than 50\% }\end{array}$ & $\begin{array}{l}\text { (5) } \\
\text { Dummy if Share } \\
\text { of Assets in } \\
\text { Company Stock } \\
\text { Greater than } 75 \%\end{array}$ \\
\hline A. Unweighted & & & & & \\
\hline$D^{\text {Elective }} \times D^{\text {After } 2006}$ & $\begin{array}{l}-0.061 \\
(0.013)\end{array}$ & $\begin{array}{l}-0.072 \\
(0.019)\end{array}$ & $\begin{array}{l}-0.106 \\
(0.021)\end{array}$ & $\begin{array}{l}-0.091 \\
(0.019)\end{array}$ & $\begin{array}{l}-0.038 \\
(0.017)\end{array}$ \\
\hline Pre-2006 unweighted mean for plans with elective deferrals & 0.388 & 0.755 & 0.609 & 0.363 & 0.168 \\
\hline $\begin{array}{l}\text { B. Weighted by Participants } \\
D^{\text {Elective }} \times D^{\text {After } 2006}\end{array}$ & $\begin{array}{l}-0.108 \\
(0.032)\end{array}$ & $\begin{array}{l}-0.117 \\
(0.057)\end{array}$ & $\begin{array}{l}-0.168 \\
(0.064)\end{array}$ & $\begin{array}{l}-0.198 \\
(0.087)\end{array}$ & $\begin{array}{l}-0.052 \\
(0.036)\end{array}$ \\
\hline Pre-2006 weighted mean for plans with elective deferrals & 0.307 & 0.675 & 0.559 & 0.266 & 0.058 \\
\hline
\end{tabular}

Note: OLS regression estimates based on a sample of 13,842 plan-year observations on ESOPs excluding plans with auto-enrollment of elective deferrals. 
Table 6. Parameter Estimates of the Impact of Diversification Provisions from PPA2006 on Selected Qualitative Measures of Company-Stock Diversification in ESOPs (Standard Errors Clustered by Plan Sponsor in Parentheses)

\begin{tabular}{|c|c|c|c|}
\hline Explanatory Variable & $\begin{array}{l}\text { (1) } \\
\text { Dummy if Plan } \\
\text { Satisfies 404(c) } \\
\text { Requirements }\end{array}$ & $\begin{array}{l}(2) \\
\text { Dummy if } \\
\text { Plan Allows only } \\
\text { Partial Participant } \\
\text { Direction } \\
\end{array}$ & $\begin{array}{l}\text { (3) } \\
\text { Dummy if Requires } \\
\text { Employer } \\
\text { Contributions Held } \\
\text { in Company Stock }\end{array}$ \\
\hline $\begin{array}{l}\text { A. Unweighted } \\
D^{\text {Elective }} \times D^{\text {After2006 }}\end{array}$ & $\begin{array}{l}0.0884 \\
(0.0183)\end{array}$ & $\begin{array}{l}-0.0826 \\
(0.0189)\end{array}$ & $\begin{array}{l}-0.0406 \\
(0.0169)\end{array}$ \\
\hline Pre-2006 unweighted mean for plans with elective deferrals & 0.500 & 0.601 & 0.156 \\
\hline $\begin{array}{l}\text { B. Weighted by Participants } \\
D^{\text {Elective }} \times D^{\text {After } 2006}\end{array}$ & $\begin{array}{l}0.101 \\
(0.0604)\end{array}$ & $\begin{array}{l}-0.278 \\
(0.0634)\end{array}$ & $\begin{array}{l}-0.0929 \\
(0.0556)\end{array}$ \\
\hline Pre-2006 weighted mean for plans with elective deferrals & 0.657 & 0.698 & 0.404 \\
\hline
\end{tabular}

Note: Regression estimates based on sample of 12,470 plan-year observations on ESOPs. 


\section{RECENT WORKING PAPERS FROM THE CENTER FOR RETIREMENT RESEARCH AT BOSTON COLLEGE}

Prescription Drug Insurance Coverage, Drug Utilization, and Cost-Related NonAdherence: Evidence from the Medicare Part D Expansion

Gary V. Engelhardt, November 2011

Social Security on Auto-Pilot: International Experience with Automatic Stabilizer Mechanisms

Barry Bosworth and R. Kent Weaver, November 2011

The Impact of Unemployment Insurance Extensions on Disability Insurance Application and Allowance Rates

Matthew S. Rutledge, October 2011

Do Couples Self-Insure? The Effect of Informal Care on a Couple's Labor Supply

Norma B. Coe, Meghan Skira, and Courtney Harold Van Houtven, October 2011

How Prepared are State and Local Workers for Retirement?

Alicia H. Munnell, Jean-Pierre Aubry, Josh Hurwitz, and Laura Quinby, October 2011

Social Security Reform and Male Labor Force Participation Around the World Jocelyn E. Finlay and Günther Fink, September 2011

Corporate Pension Plan Investments in Alternative Assets: Determinants and Consequences

Divya Anantharaman, August 2011

Social Security Reform and Male Labor Force Participation Around the World Jocelyn E. Finlay and Günther Fink, June 2011

An In-Depth Look into Intergenerational Flows

Oksana Leukhina and Marika Santoro, May 2011

Who Retires Early?

Henry J. Aaron and Jean Marie Callan, May 2011

The Potential Impact of the Great Recession on Future Retirement Incomes Barbara A. Butrica, Richard W. Johnson, and Karen E. Smith, May 2011

Immigrant Diversity and Social Security: Recent patterns and Future Prospects Melissa M. Favreault and Austin Nichols, May 2011

All working papers are available on the Center for Retirement Research website (http://crr.bc.edu) and can be requested by e-mail (crr@bc.edu) or phone (617-552-1762). 